\title{
Objective Evaluation OF Upright And Grand Pianos by Measuring Play-BenCh
}

\author{
Jana Urbánková \\ VÚTS, a.s., Measurement Department, \\ Svárovská 619, Liberec XI - Růžodol I, 46001 Liberec, Czech Republic \\ e-mail: jana.urbankova@vuts.cz
}

\begin{abstract}
This article describes the measuring equipment which is used in the objective evaluation of pianos. This equipment in the form of a play-bench replays each key of the piano keyboard separately, making it possible to measure the acoustics such as sound pressure level and tone reverberation length. Objective evaluation of such a complicated instrument as the piano is a very complex task. An integral part of evaluation is the psychoacoustic dimension and the conversion of subjective perceptions into objective acoustical values.
\end{abstract}

\section{Keywords}

Piano; Play-bench; Striking pins; Acoustics; Psychoacoustics.

\section{Introduction}

The piano is a very complicated musical instrument and it is relatively new, first introduced in the 18th century and evolving to the current appearance of the grand piano in 19th century [3]. In comparison with other musical instruments, the piano offers huge possibilities of playing. The enormous range of loudness consists the name itself - "pianoforte" (piano = quietly, forte = loud).

The traditional manufacture of musical instruments is a highly prestigious handcraft, and famous producers base their reputation on precise handmade work. So when they are assessed, it cannot be practically circumvented without a subjective evaluation. Simply the evaluation of the musical sound itself is very narrow specialization [1] and [2]. If the manufacturer wants to find out the quality of their instrument, they are practically always dependent on professional players' opinion. This form of feedback is lengthy and uneconomical in many ways. For the manufacturer it is very complicated to round up more players together, ensure equal conditions for everyone and compare their answers, which are often very specific. Next problem is the fact that players (especially pianists) are often unable to separate the perception of the sound from the perception of running the mechanics; it is said that "they hear with their hands". It is therefore increasingly necessary for manufacturers to evaluate their instruments in an objective way so that they can compare each other and go forward with their own development.

The branch of science called psychoacoustics deals with the subjective percept transfer into objective data and use the knowledge of human perception [6].

\section{Research Objective}

In the first place, the research objective is to modernize and rebuild the original play-bench for new measurement requirements and finding a suitable measurement methodology. 
Big advantages of objective measurement are specifications of clearly and repeatable measurement conditions and results presented by a single value. The evaluation and comparison of single instruments becomes much easier.

At the end of the 1960s, measuring equipment [5] was developed in the State School of Music in Warsaw for Czechoslovak musical instruments. This device consisted mainly of a bench used in Petrof company for research and development [4] in the 1990s. In the last two years, the play-bench was renovated and upgraded to offer greater possibilities for measuring pianos.

\subsection{The Original Play-Bench of Petrof}

The original play-bench (shown in Fig. 1) was composed of aluminium rail on which two striking pins were moved - one for the white keys and the second for the black ones. A system of metallic contacts on the rail allowed the pin to stop above the particular key. Then the key was excited by the striking pin with a defined power. The pins consisted of a pair of electromagnets and a set of two artificial fingers. The artificial fingers were conical in shape and were made of teflon. The keystroke was performed by the free fall of the pin on the key. The movement of the pins and the measurement was realized by the control system (Fig. 2) remotely.

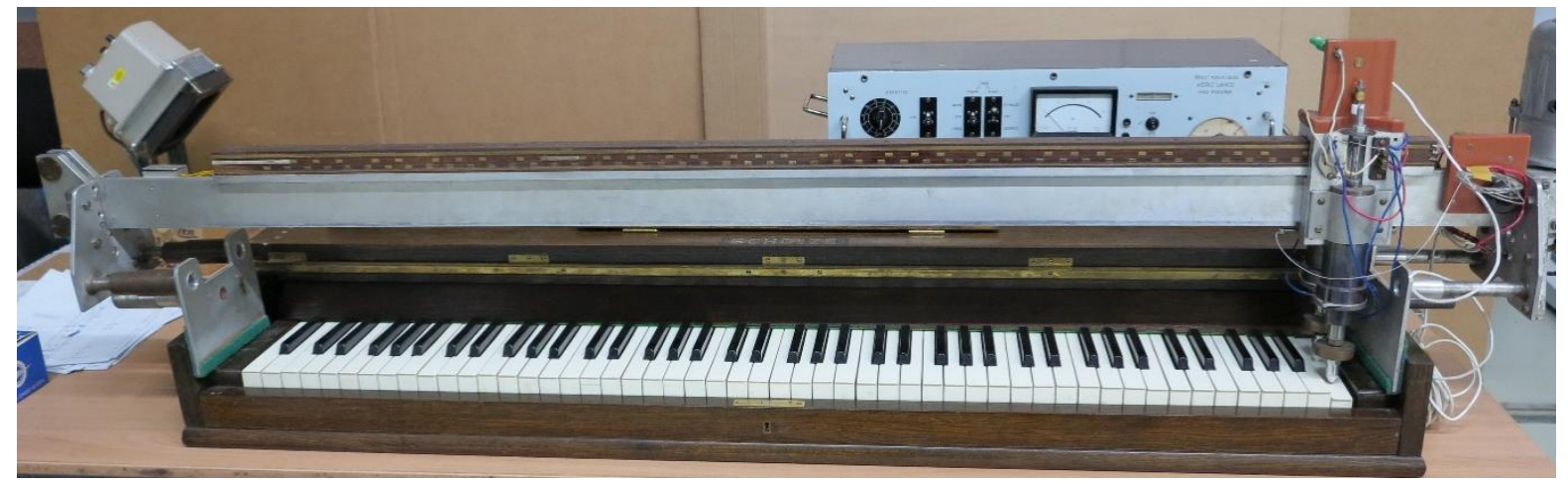

Source: Own

Fig. 1: Original equipment constructed in 1960s

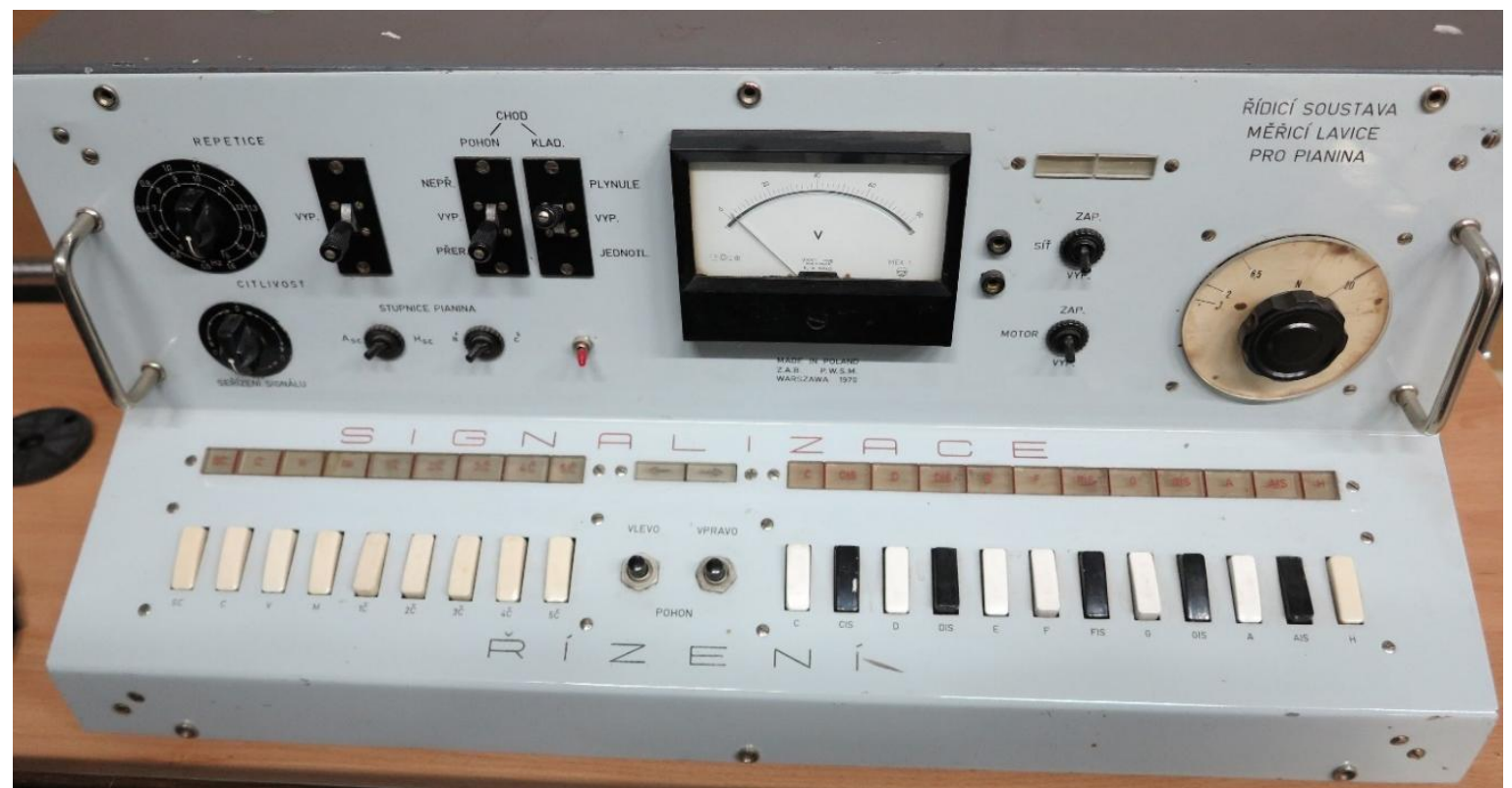

Source: Own

Fig. 2: The control system for measurement settings of the original play-bench 
Because of obsolete system, long time inactivity and need of wider setting of play-bench, the measuring equipment was rebuilt for the need of the Petrof company, involving modernizing the control system and adapting it for easier programming.

\subsection{Rebuilding and Modernization of the Play-Bench}

Only the set of electromagnets and both pins were used from the original device and they were also partially modified. The aluminium rail was replaced by a steel girder and universal clamping brackets which hold the equipment onto the piano. The pins are transported along a circular slide way and move using a toothed belt and a stepper motor. The new play-bench is shown in Fig. 3. An industrial computer (PLC) is used to control and set the measurement (shown in Fig. 4). This allows us to change the setting of the measured range and the play mode, the time of the keystroke and the time between the pins movement and the keystroke.

The entire device was modified in particular to measure the full dynamic range of the instrument. The keystroke is performed by free fall, so it is possible to control and vary its impact force only by additional weights and adjustment of the height of the artificial fingers. Compared to the original adjustment of the pins height, when it was necessary to change the internal structure of the pins, the height $(2-20 \mathrm{~mm}$ above the keyboard, including the possibility of adding weight) is set directly by the artificial fingers.

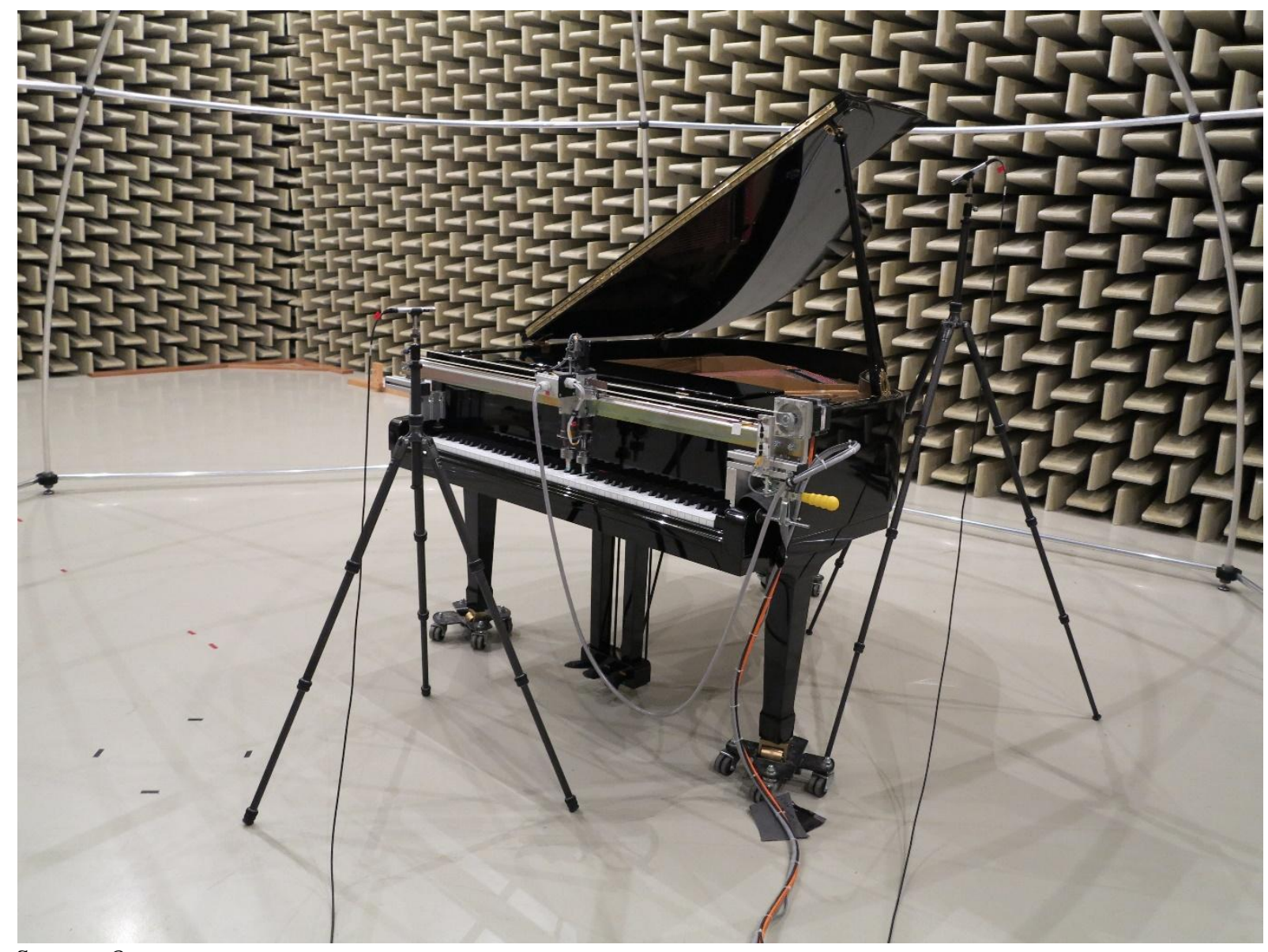

Source: Own

Fig. 3: The rebuilt and modernized play-bench 


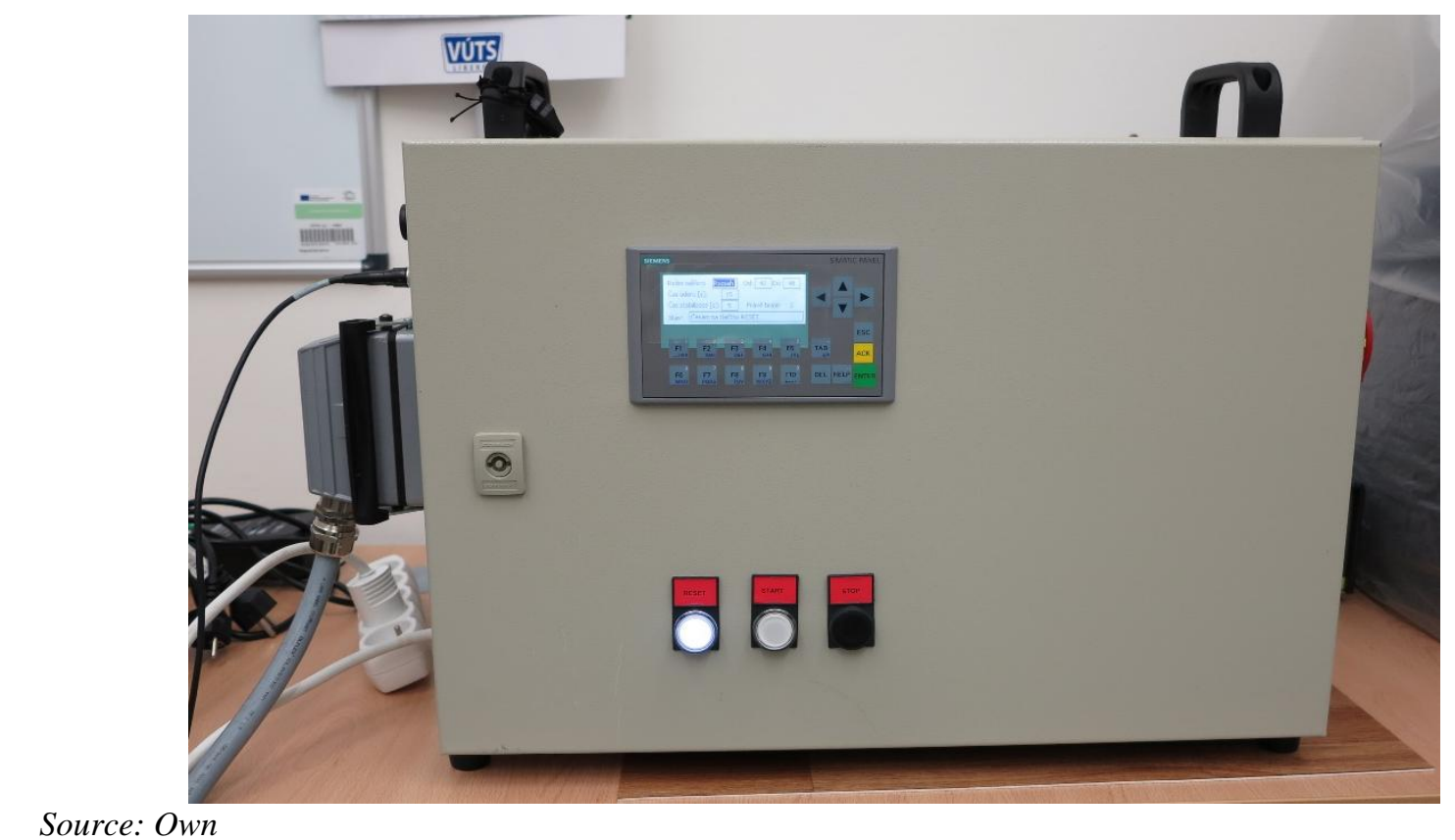

Fig. 4: The industrial computer for control and measurement setting

Source: Own

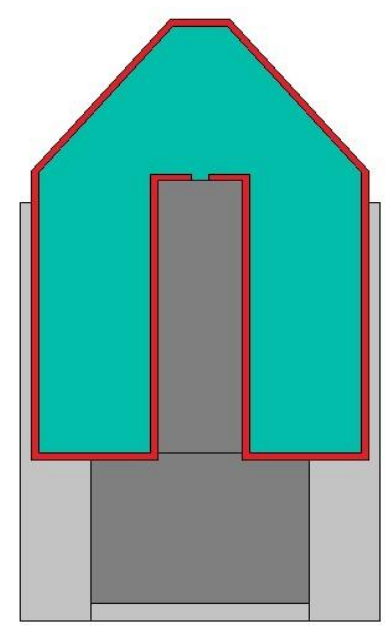

Fig. 5: Scheme of the artificial finger structure:

red-teflon tape, turquoise - silicone head, dark gray - reinforcing screw

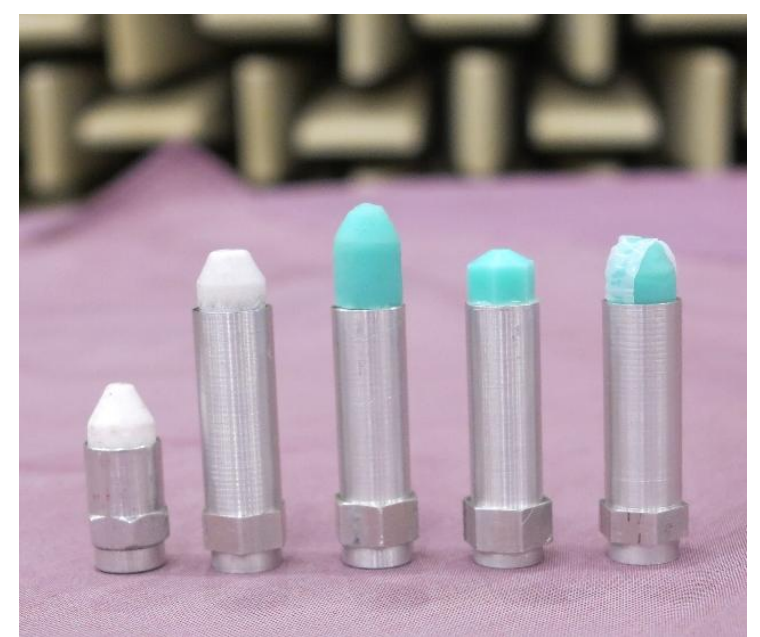

Source: Own

Fig. 6: The development of artificial fingers to the far left: original artificial finger made of teflon, to the far right: the final form of artificial finger made of addition silicone and teflon tapes

\subsection{The Striking Pins}

As has been said, one of the important claims of the modernization was the ability to play the keys in the full dynamic range of the instrument. This is mainly influenced by the appearance of the artificial fingers. Many shapes and materials were tested in the past, particularly because of the durability of the material and the ability to easily slip over the key surface. Original fingers were constructed with the bevelled cylindrical pins from teflon. This solution had lots of advantages - there was no deformation after repeated use, the location of striking on the key was sufficiently defined, and friction was minimized. But it was unusable for the lowest dynamics because of the hard material that made a lot of noise by the keystroke. 
Therefore, new artificial fingers were made of soft addition silicone, which is very close to the silicones used in orthopaedics and prosthetics. A thin teflon foil is also attached to the surface of the silicone finger to ensure easy slipping on the key. A simple diagram of a silicone artificial finger is shown in Fig. 5 and the development of the artificial fingers themselves is illustrated in Fig. 6.

\section{The Methods of Research}

Methods of research represent mainly measurements of instruments themselves, verification of these measurements and subsequent comparison of achieved results.

\section{The Measurement}

After the final adjustment and modification of the measuring play-bench, three pianos were measured - two upright pianos and one grand piano. All instruments were measured in semianechoic chamber with two microphones positions - objective and "psychoacoustics". The first (objective) position is different for upright pianos and for grand pianos. For the upright piano, the microphone is placed $1 \mathrm{~m}$ high at a distance of $1 \mathrm{~m}$ on the axis perpendicular to the surface of the soundboard and in case of the grand piano; the microphone is positioned in the extension of the right edge of the instrument, $160 \mathrm{~cm}$ high and parallel to the opened main lid. The position of the microphone for the psychoacoustic measurement is in the location of the player.

\subsection{Measurement Settings}

Five specifications of dynamics for the measurement were determined. These specifications differed in the height and weight of the striking pins with the same step. It was found that the maximum weight of the striking pin for the black keys was lower than for the white keys because of different inner stroke mechanism and treatment of the key surface itself. While the maximum weight of the additional weights is given by the play-bench options, or by the electromagnets options, the minimum weight is given by the possibilities of individual instruments and must be determined for each instrument individually.

Replaying of keys was done in the "All" play-mode, so that all 88 keys on the keyboard were replayed sequentially.

\subsection{Evaluation}

For objective comparison of each instrument, it is necessary to reduce a large amount of data (88 keys) to a single number that evaluates the entire range of the instrument or (better) to three values corresponding to distribution of the range according to Tab. 1.

Tab. 1: Dividing the keyboard range into approximately three equal groups

\begin{tabular}{|l|c|c|}
\hline Distribution & Tone range (German notation) & Order of tones on the play-bench \\
\hline bass & A $2-\mathrm{d}$ & $88-59$ \\
\hline alto & dis - gis 2 & $58-29$ \\
\hline descant & a $2-$ c5 & $28-1$ \\
\hline
\end{tabular}

Source: Own

The range of piano dynamics is according to the literature from $40 \mathrm{~dB}$ to $100 \mathrm{~dB}$. Tab. 2 shows a more detailed distribution. 
Tab. 2: Theoretical range of piano dynamics

Source: [7]

\begin{tabular}{|l|c|c|}
\hline Dynamics & Sound pressure level [dB] & Tolerance [dB] \\
\hline ppp (piano pianissimo) & 40 & \pm 5 \\
\hline pp (pianissimo) & 50 & \pm 5 \\
\hline p (piano) & 60 & \pm 2.5 \\
\hline mp (mezzopiano) & 65 & \pm 2.5 \\
\hline mf (mezzoforte) & 70 & \pm 2.5 \\
\hline f (forte) & 80 & \pm 5 \\
\hline ff (fortissimo) & 90 & \pm 5 \\
\hline fff (forte fortissimo) & 100 & \pm 5 \\
\hline
\end{tabular}

The time records of the sound pressure signals were obtained by the measuring system. From these time records, the waveforms of sound pressure levels were evaluated, weighted by the filter A and exponentially averaged with a time constant of $\tau=1 / 8 \mathrm{~s}$. This setting represents the acoustic emission as perceived by the human ear. After that, the maxima of sound pressure levels for each key were found in different dynamics and the overall "loudness" of individual pianos was evaluated. The term of loudness is not defined here by psychoacoustic metric but for the comparison of instruments it is sufficient to define the maximum sound pressure level.

Together with the waveforms of tones, the tone reverberation length of the individual keys and the whole instrument were determined. An example of the tone reverberation length of tones a4 (descant), a1 (alto) and A1 (bass) is shown in Fig. 7.
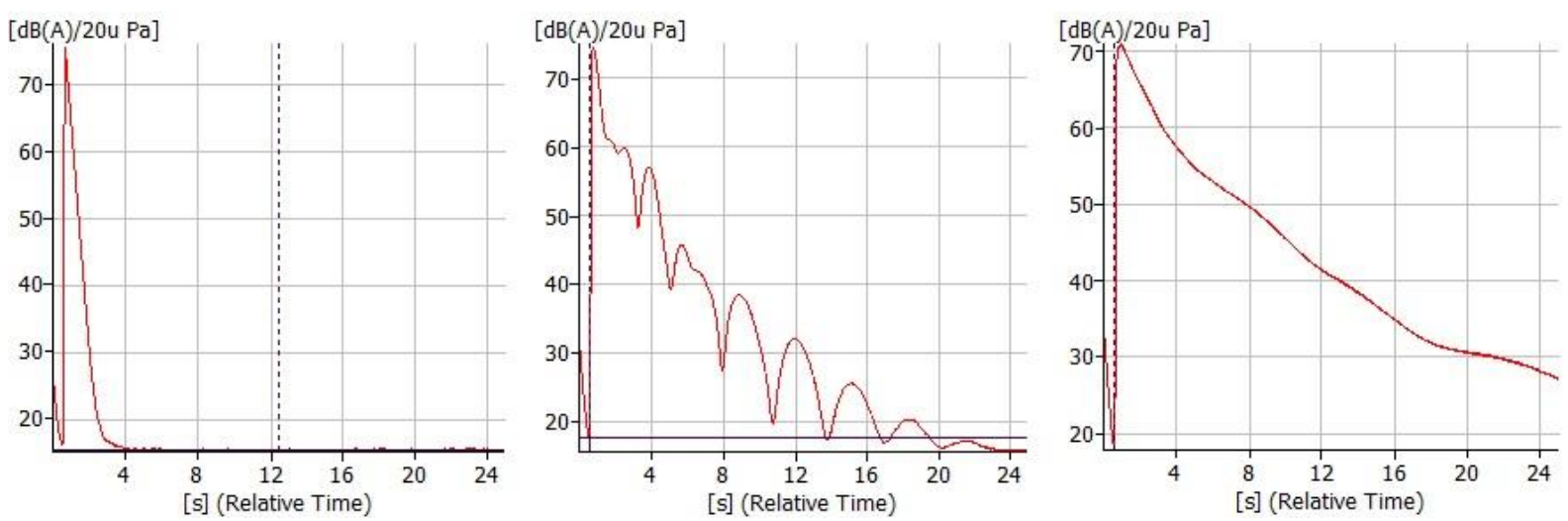

Source: Own

Fig. 7: The sound pressure level depending on time, tones a4 (descant), al (alto) and A1 (bass) (left to right) in German notation

Tab. 3 to 5 show the results of the total sound pressure level $L_{p}(A)$ and tone reverberation length $t_{r}$ for different dynamics over the entire instruments range. The "D1" represents the lowest dynamic and "D5" the loudest one. 
Tab. 3: Total sound pressure level and tone reverberation length for different dynamics over the entire range of upright piano 1

\begin{tabular}{|l|c|c|c|c|}
\hline Upright piano 1 & \multicolumn{2}{|c|}{ Microphone 1 (objective) } & Microphone 2 (psychoacoustic) \\
\hline Dynamics & $\boldsymbol{L}_{\boldsymbol{p}}(\boldsymbol{A})[\mathbf{d B}]$ & $\boldsymbol{t}_{\boldsymbol{r}}[\mathbf{s}]$ & $\boldsymbol{L}_{\boldsymbol{p}}(\boldsymbol{A})[\mathbf{d B}]$ & $\boldsymbol{t}_{\boldsymbol{r}}[\mathbf{s}]$ \\
\hline D1 & 64.52 & 4.57 & 61.38 & 3.94 \\
\hline D2 & 76.76 & 8.28 & 70.32 & 6.01 \\
\hline D3 & 82.02 & 9.91 & 74.82 & 7.51 \\
\hline D4 & 84.81 & 10.79 & 77.48 & 8.05 \\
\hline D5 & 86.42 & 11.13 & 79.02 & 8.36 \\
\hline
\end{tabular}

Source: Own

Tab. 4: Total sound pressure level and tone reverberation length for different dynamics over the entire range of upright piano 2

\begin{tabular}{|l|c|c|c|c|}
\hline Upright piano & \multicolumn{2}{|c|}{ Microphone 1 (objective) } & \multicolumn{2}{c|}{ Microphone 2 (psychoacoustic) } \\
\hline Dynamics & $\boldsymbol{L}_{\boldsymbol{p}}(\boldsymbol{A})[\mathbf{d B}]$ & $\boldsymbol{t}_{\boldsymbol{r}}[\mathbf{s}]$ & $\boldsymbol{L}_{\boldsymbol{p}}(\boldsymbol{A})[\mathbf{d B}]$ & $\boldsymbol{t}_{\boldsymbol{r}}[\mathbf{s}]$ \\
\hline D1 & 63.79 & 4.71 & 57.40 & 3.37 \\
\hline D2 & 77.03 & 8.38 & 67.31 & 5.51 \\
\hline D3 & 81.19 & 9.57 & 73.76 & 7.67 \\
\hline D4 & 83.87 & 10.22 & 76.34 & 8.39 \\
\hline D5 & 85.83 & 10.90 & 78.26 & 8.92 \\
\hline
\end{tabular}

Source: Own

Tab. 5: Total sound pressure level and tone reverberation length for different dynamics over the entire range of grand piano

\begin{tabular}{|l|c|c|c|c|}
\hline Grand piano & \multicolumn{2}{|c|}{ Microphone 1 (objective) } & \multicolumn{2}{c|}{ Microphone 2 (psychoacoustic) } \\
\hline Dynamics & $\boldsymbol{L}_{\boldsymbol{p}}(\boldsymbol{A})[\mathbf{d B}]$ & $\boldsymbol{t}_{\boldsymbol{r}}[\mathbf{s}]$ & $\boldsymbol{L}_{\boldsymbol{p}}(\boldsymbol{A})[\mathbf{d B}]$ & $\boldsymbol{t}_{\boldsymbol{r}}[\mathbf{s}]$ \\
\hline D1 & 65.60 & 5.93 & 61.38 & 3.94 \\
\hline D2 & 78.17 & 9.45 & 72.44 & 7.15 \\
\hline D3 & 83.87 & 11.57 & 78.21 & 8.88 \\
\hline D4 & 86.88 & 12.52 & 81.17 & 9.50 \\
\hline D5 & 88.64 & 12.93 & 82.80 & 9.94 \\
\hline
\end{tabular}

Source: Own

\section{Conclusion}

The improved and upgraded play-bench allows us to reliably replay each key of the piano keyboard with a defined and standardized keystroke in the dynamic range from piano $(p)$ to fortissimo (ff), which is sufficient for general piano ratings. Limitations of the lowest dynamics are mainly due to the instruments themselves and their inner mechanisms. The playbench is also universally applicable to any type of upright or grand piano thanks to the universally adjustable construction.

Two upright pianos and one grand piano were measured and evaluated using the play-bench. Based on the sound pressure measurement, the overall sound pressure level (overall "loudness") of the individual instruments and the tone reverberation length were evaluated for five defined dynamics. The correct functionality and limits of the play-bench were verified during the measurement. 


\section{Acknowledgements}

This project has been supported by the CTU research project SGS16/221/OHK3/3T/13 Measurement, modelling and evaluation methods in acoustics and by the Czech Ministry of Education, project LO1213.

The author would also like to thank the company Petrof.

\section{Literature}

[1] TERHARDT, E.: Psychoacoustic evaluation of musical sounds. Perception \& Psychophysics. 1978, 23(6), pp. 483-492. ISSN 0031-5117. DOI: $\underline{10.3758 / B F 03199523}$

[2] SYROVÝ, V.: Hudební akustika. 3. doplněné vydání. Praha: Akademie múzických umění, 2013. Akustická knihovna Zvukového studia Hudební fakulty AMU. ISBN 97880-7331-297-8.

[3] GIORDANO, N. J.: Physics of the piano. Oxford: Oxford University Press, 2010. ISBN 0199546029.

[4] NOSEK, J.; RAFFAJ, A.: Objektivni měreni akustických vlastností pian. Výzkumněvývojové středisko s. p. Petrof, 1991.

[5] BOBILEWICZ, Z:: Universalna LAWA Pomiarova do Poloautomatycznej Kontroly Pianin. Warzawa: AM Chopina, 1970.

[6] MELKA, A.: Základy experimentální psychoakustiky. 1. vyd. Praha: Akademie múzických umění v Praze, 2005. ISBN 80-7331-043-0.

[7] KURFÜRST, P.: Základy hudební akustiky. Brno: Masarykova univerzita, 2000. ISBN 80-210-2333-3.

Ing. Jana Urbánková 


\section{OBJEKTIVNÍ HODNOCENÍ PIANIN A KLAVÍRU POMOCÍ PŘEHRÁVACÍ LAVICE}

Tento článek popisuje měřicí zařízení používané při objektivním hodnocení pian. Zařízení $\mathrm{v}$ podobě přehrávací lavice samostatně přehraje každou klávesu na klaviatuře a umožní tak změření akustických vlastností, jako je hladina akustického tlaku a délka doznívání tónu. Objektivní hodnocení tak složitého nástroje, jako je klavír, je velmi komplexní úkol. Nedílnou součástí hodnocení je psychoakustický rozsah a přeměna subjektivního vnímání na objektivní akustické hodnoty.

\section{Objektive Bewertung Der Pianinos Und Klaviere Mit DeR Messbank}

Dieser Artikel beschreibt ein Messgerät, das bei der objektiven Bewertung von Klavieren verwendet wird. Dieses Gerät in Form einer Messbank überspielt unabhängig jede Taste der Klaviertastatur und ermöglicht die Messung akustischer Eigenschaften wie Schalldruckpegel und Tonausklanglänge. Die objektive Beurteilung eines so komplizierten Instruments wie des Klaviers eine sehr komplexe Aufgabe. Ein wesentlicher Bestandteil der Bewertung ist die psychoakustische Dimension und die Umwandlung subjektiver Wahrnehmungen in objektive akustische Werte.

\section{OBIEKTYWNA OCENA PIANIN I FORTEPIANÓW ZA POMOCĄ ŁAWKI ODTWARZAJĄCEJ}

W niniejszym artykule opisano urządzenie pomiarowe używane do obiektywnej oceny pianin. Urządzenie w postaci ławki odtwarzającej odtwarza oddzielnie każdy klawisz klawiatury, umożliwiając pomiar cech akustycznych takich jak poziom ciśnienia akustycznego i długość rezonansu dźwięku. Obiektywna ocena tak skomplikowanego instrumentu, jakim jest fortepian, jest bardzo kompleksowym zadaniem. Integralną częścią oceny jest zakres psychoakustyczny i konwersja subiektywnego odbioru na obiektywne wartości akustyczne. 